\title{
Satellite observations of aerosols and clouds over southern China from 2006 to 2015: analysis of changes and possible interaction mechanisms
}

Nikos Benas et al.

Correspondence to: Nikos Benas (benas@knmi.nl)

The copyright of individual parts of the supplement might differ from the CC BY 4.0 License. 


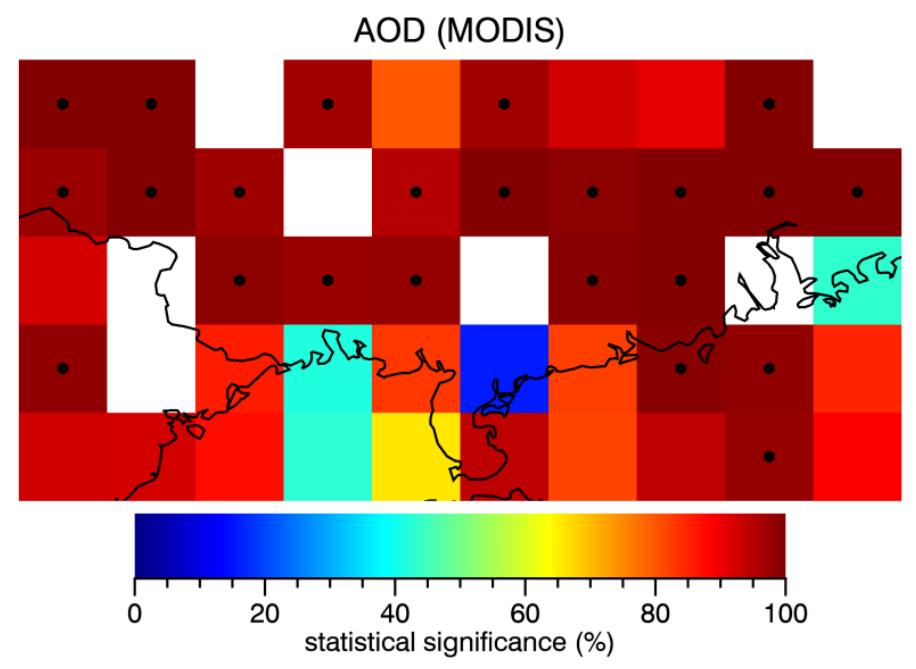

Figure S1. Levels of statistical significance for MODIS AOD changes over southern China, calculated for the period 2006-2015. The black dots highlight the grid cells where the level of statistical significance is higher than $95 \%$. White areas correspond to grid cells where the threshold regarding time series completeness was not met. 
(a)

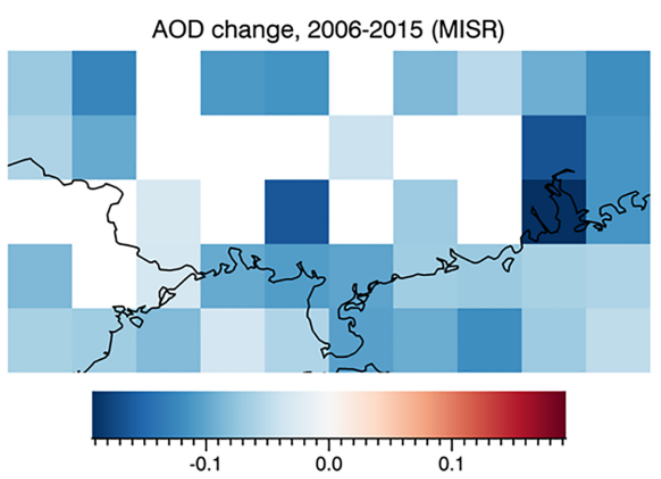

(c)

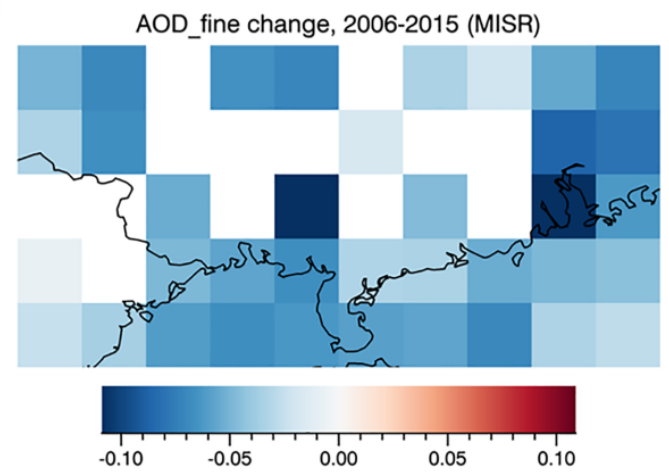

(e)

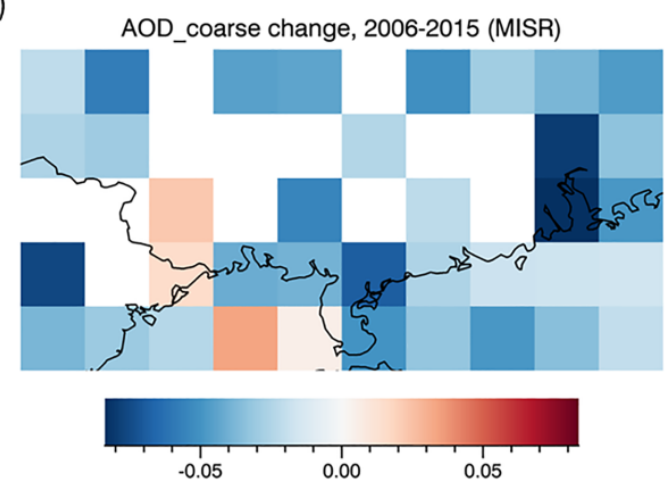

(b)



(d)



(f)



Figure S2. Changes in total, fine and coarse mode AOD over southern China during 2006-2015 deduced from MISR data. (a, c, e) Spatial distributions of total, fine and coarse mode AOD change over the study region and (b, $d, f)$ corresponding levels of statistical significance. The black dots in (b), (d) and (f) highlight the grid cells where the level of statistical significance is higher than $\mathbf{9 5 \%}$. White areas correspond to grid cells where the threshold regarding time series completeness was not met. 
Table S1. Statistical measures of changes in AOD and cloud properties over southern China in 2006-2015 based on data products from CALIPSO, MISR, MODIS and CLARA-A2. Measures comprise percent changes, slopes and p-values.

\begin{tabular}{|c|c|c|c|c|c|}
\hline Parameter & Unit & CALIPSO & MISR & MODIS & CLARA-A2 \\
\hline & & $\begin{array}{l}\text { Change }(\%) / \text { slope } \\
\left(<\text { unit> }>\mathrm{yr}^{-1}\right) / \mathrm{p} \text {-value }\end{array}$ & $\begin{array}{l}\text { Change }(\%) / \text { slope } \\
\left(<\text { unit> }>r^{-1}\right) / p \text {-value }\end{array}$ & $\begin{array}{l}\text { Change }(\%) / \text { slope } \\
\left(<\text { unit }>\mathrm{yr}^{-1}\right) / \mathrm{p} \text {-values }\end{array}$ & $\begin{array}{l}\text { change }(\%) / \text { slope } \\
\left(<\text { unit }>\mathrm{yr}^{-1}\right) / \mathrm{p} \text {-value }\end{array}$ \\
\hline Total AOD & 1 & $-23.3 /-0.013 / 0.013$ & $-17.9 /-0.008 / 0.007$ & $-17.6 /-0.010 / 0.002$ & \\
\hline Fine AOD & 1 & & $-20.7 /-0.005 / 0.005$ & & \\
\hline Coarse AOD & 1 & & $-14.3 /<-0.001 / 0.042$ & & \\
\hline Dust AOD & 1 & & $-13.1 /-0.001 / 0.332$ & & \\
\hline All-sky LWP & $\mathrm{g} \mathrm{m}_{2}^{-}$ & & & $+12.4 / 0.837 / 0.204$ & $+14.2 / 0.913 / 0.242$ \\
\hline Liquid CFC & 1 & & & $+6.8 / 0.003 / 0.219$ & $+3.4 / 0.002 / 0.465$ \\
\hline Liquid COT & 1 & & & $+5.5 / 0.089 / 0.399$ & $+3.6 / 0.058 / 0.607$ \\
\hline Liquid REFF & $\mu \mathrm{m}$ & & & $+1.6 / 0.018 / 0.239$ & $+5.2 / 0.034 / 0.0003$ \\
\hline
\end{tabular}



Figure S3. Seasonal variation in aerosols and precursor gases from the Copernicus Atmosphere Monitoring Service (CAMS), relative to the annual emission of each species, over southern China during 2006-2015. 
(a)

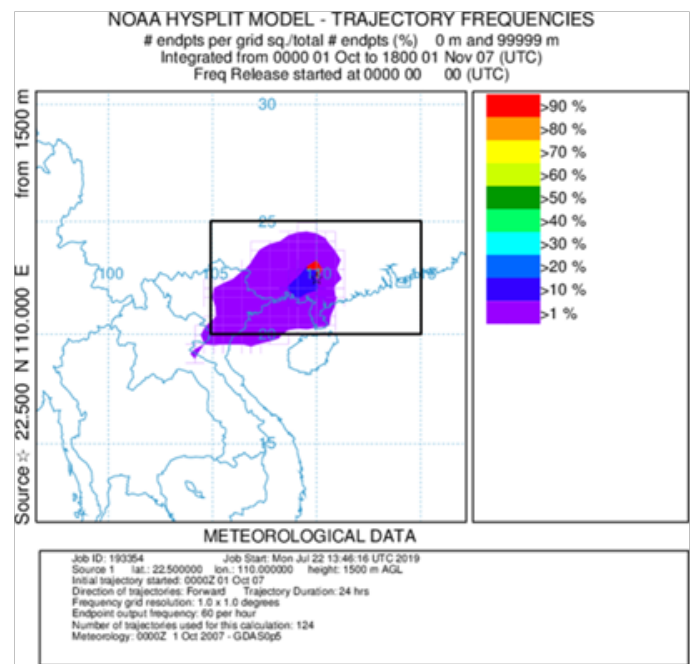

(c)

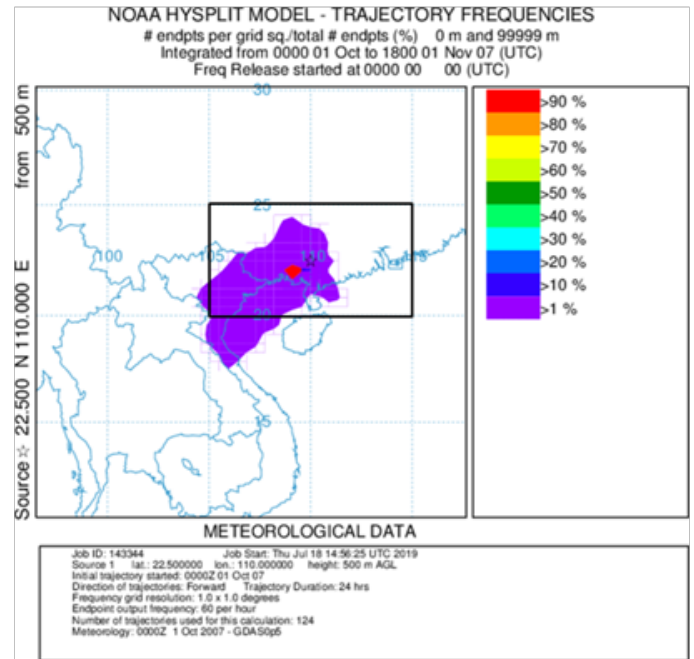

(b)

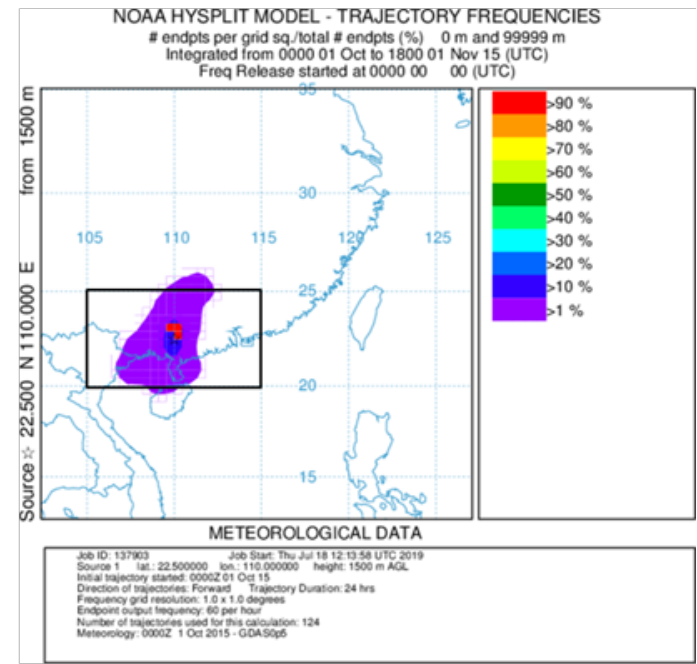

(d)



Figure S4. Forward trajectories frequency calculated based on HYSPLIT model for October $2007(a, c)$ and $2015(b, d)$, starting at the center of the study region $\left(22.5^{\circ} \mathrm{N}, 110.0^{\circ} \mathrm{E}\right)$ and at $500 \mathrm{~m}(\mathrm{c}, \mathrm{d})$ and $1500 \mathrm{~m}(\mathrm{a}, \mathrm{b})$ above sea level (a.s.l.). The patterns show the frequency of trajectory occurrence (in \% relative to the total number of trajectories), that end in each pixel. The study region is indicated by a black rectangle. 
(a)



(c)

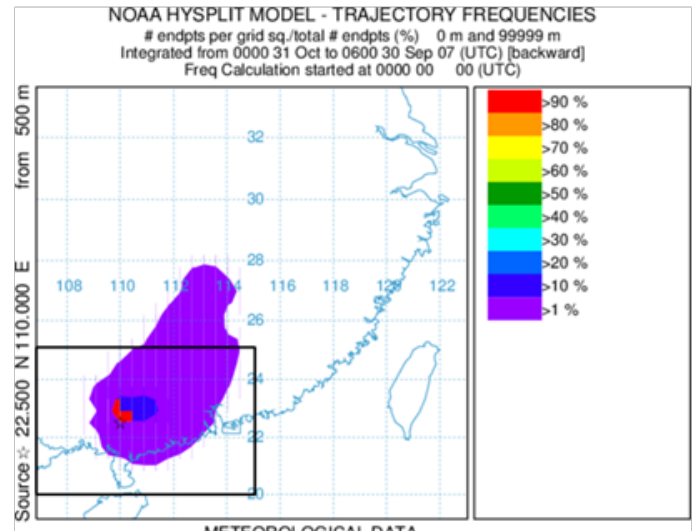

METEOROLOGICAL DATA

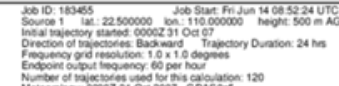

todom (b)

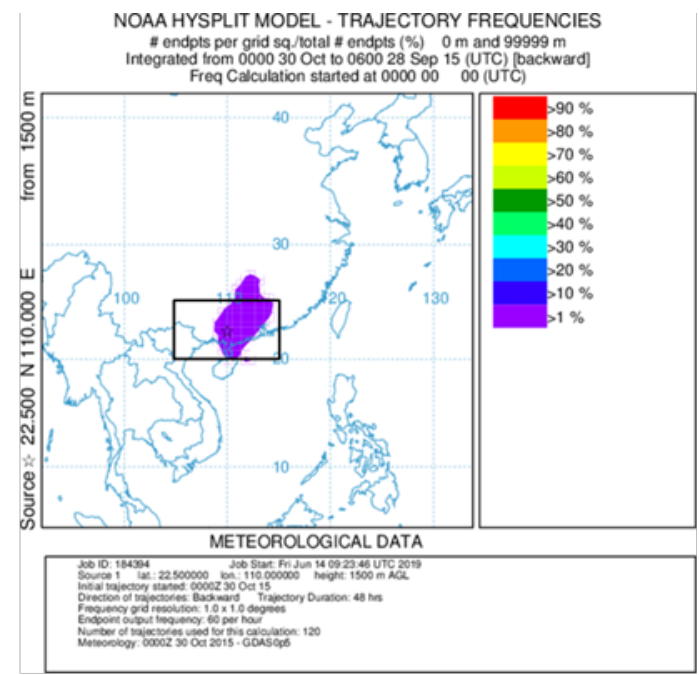

(d)

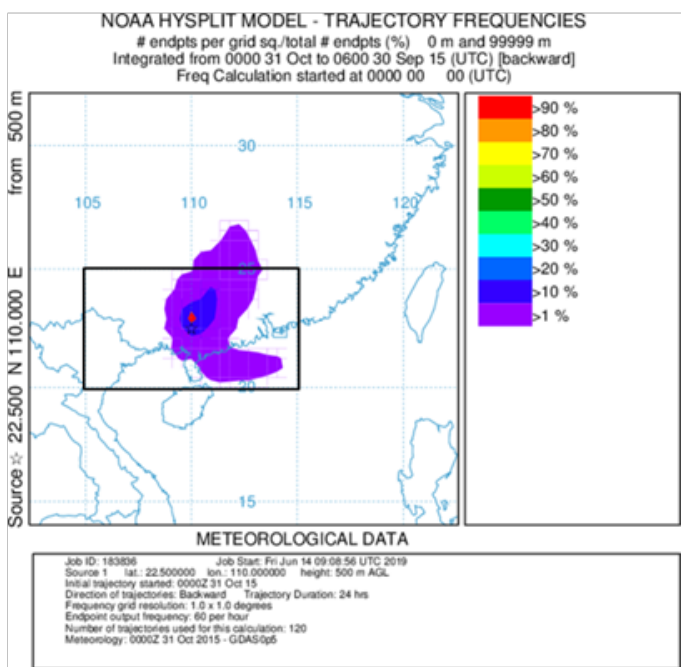

Figure S5. Back-trajectories frequency calculated based on HYSPLIT model for October 2007 (a, c) and 2015 (b, d), ending at the center of the study region $\left(22.5^{\circ} \mathrm{N}, 110.0^{\circ} \mathrm{E}\right)$ and at $500 \mathrm{~m}(\mathrm{a}, \mathrm{b})$ and $1500 \mathrm{~m}(\mathrm{c}, \mathrm{d})$ above sea level (a.s.l.). The patterns show the frequency of trajectory occurrence (in \% relative to the total number of trajectories), that start in each pixel. The study region is indicated by a black rectangle. 
(a)



(c)

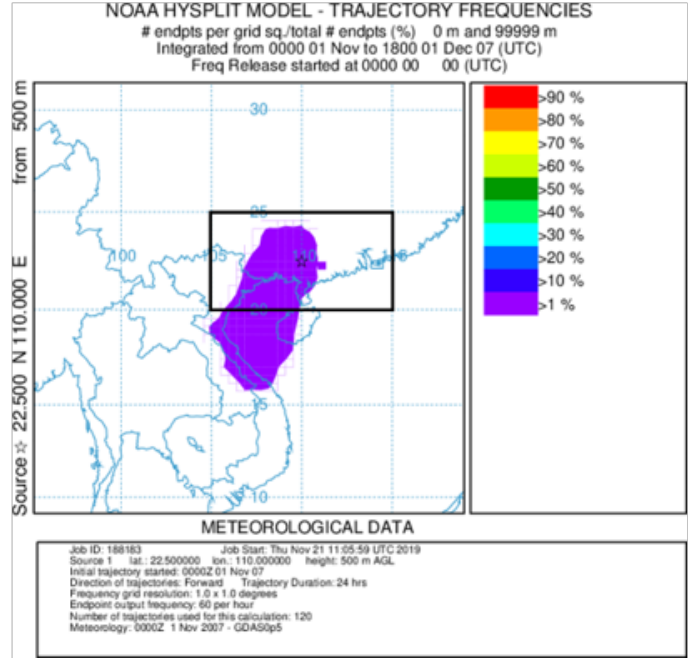

(b)

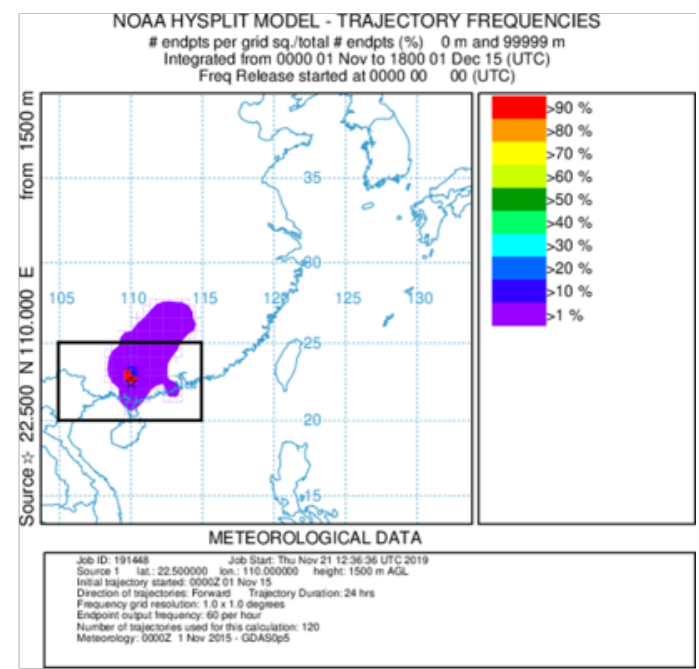

(d)

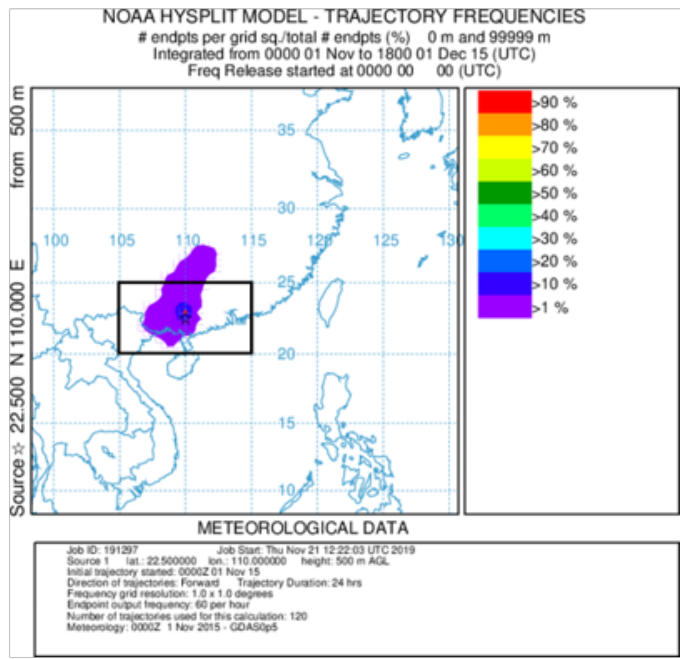

Figure S6. Forward trajectories frequency calculated based on HYSPLIT model for November 2007 (a, c) and 2015 (b, d), starting at the center of the study region $\left(22.5^{\circ} \mathrm{N}, 110.0^{\circ} \mathrm{E}\right)$ and at $500 \mathrm{~m}(\mathrm{c}, \mathrm{d})$ and $1500 \mathrm{~m}(\mathrm{a}, \mathrm{b})$ above sea level (a.s.l.). The patterns show the frequency of trajectory occurrence (in \% relative to the total number of trajectories), that end in each pixel. The study region is indicated by a black rectangle. 
(a)

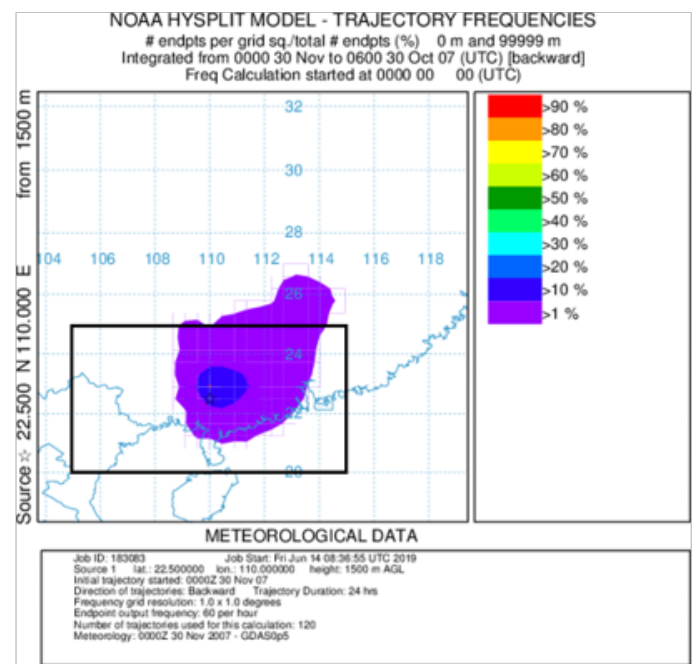

(c)

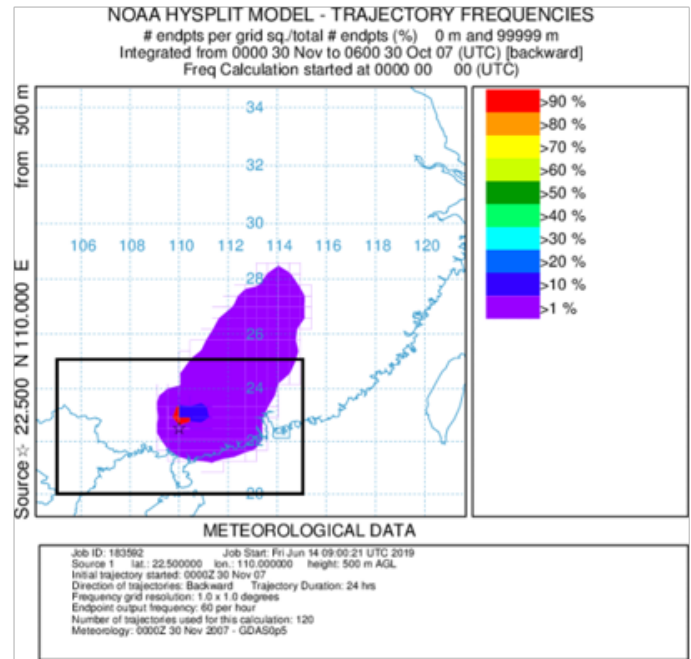

(b)

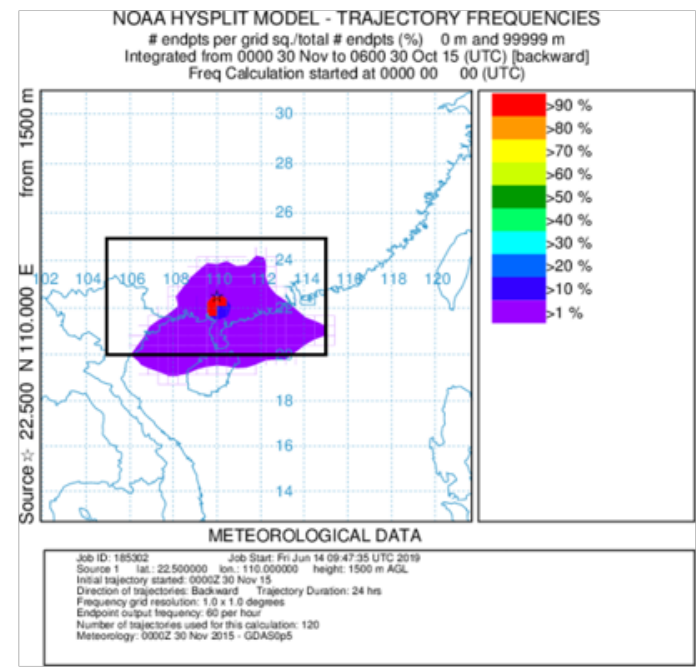

(d)

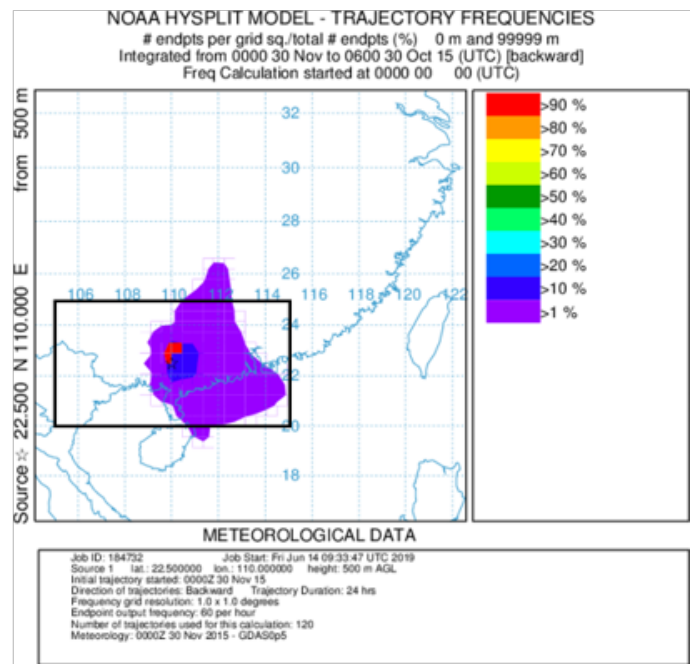

Figure S7. Back-trajectories frequency calculated based on HYSPLIT model for November 2007 (a, c) and 2015 (b, d), ending at the center of the study region $\left(22.5^{\circ} \mathrm{N}, 110.0^{\circ} \mathrm{E}\right)$ and at $500 \mathrm{~m}(\mathrm{a}, \mathrm{b})$ and $1500 \mathrm{~m}(\mathrm{c}, \mathrm{d})$ above sea level (a.s.l.). The patterns show the frequency of trajectory occurrence (in \% relative to the total number of trajectories), that start in each pixel. The study region is indicated by a black rectangle. 
(a)

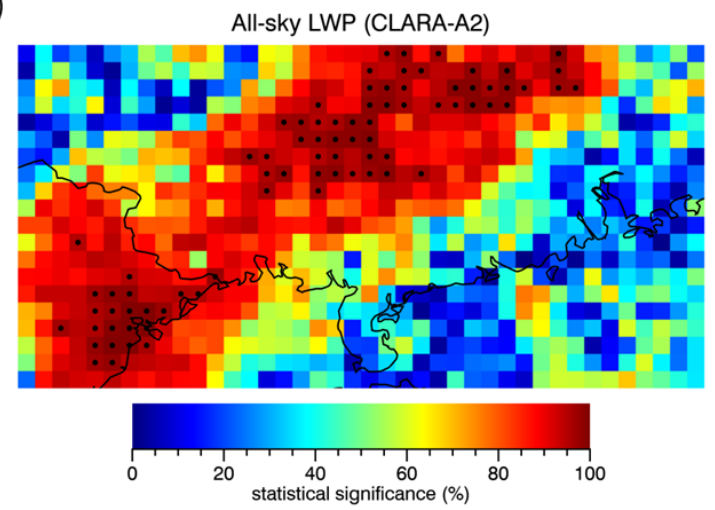

(b)

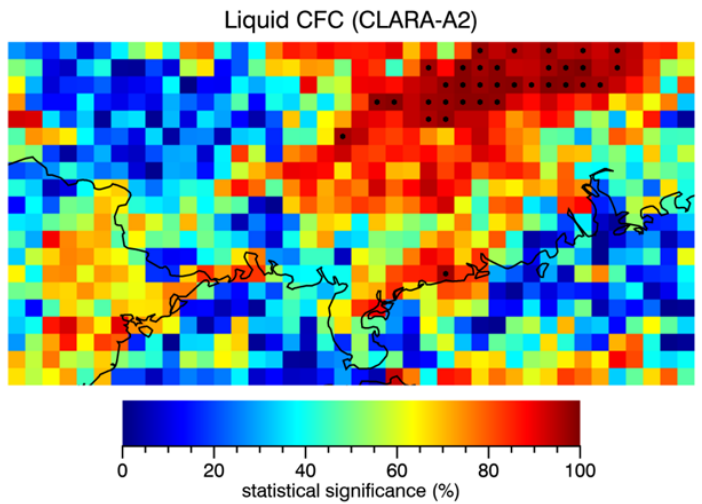

Figure S8. Levels of statistical significance for CLARA-A2 all-sky LWP and liquid CFC changes over southern China, calculated for the period 2006-2015. The black dots highlight the grid cells where the level of statistical significance is higher than $95 \%$.

(a)

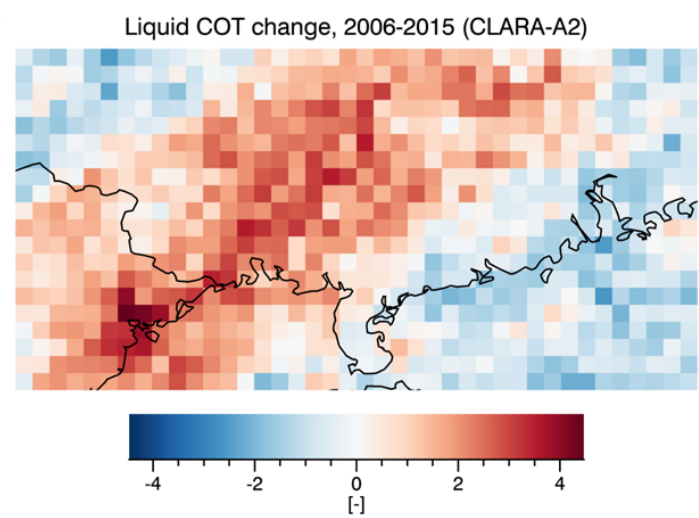

(c)

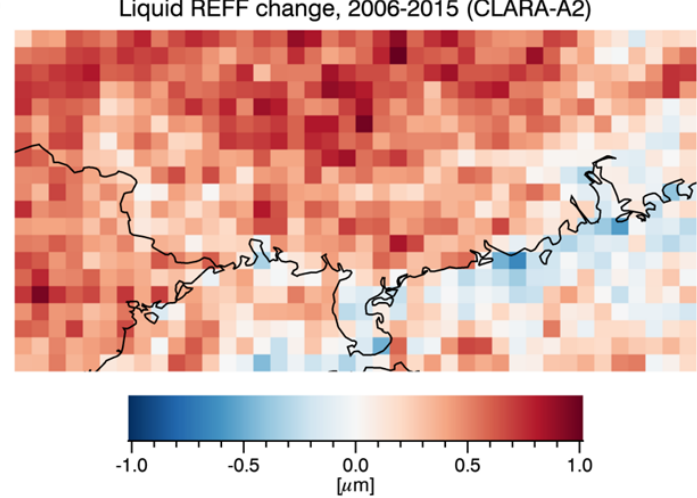

(b)

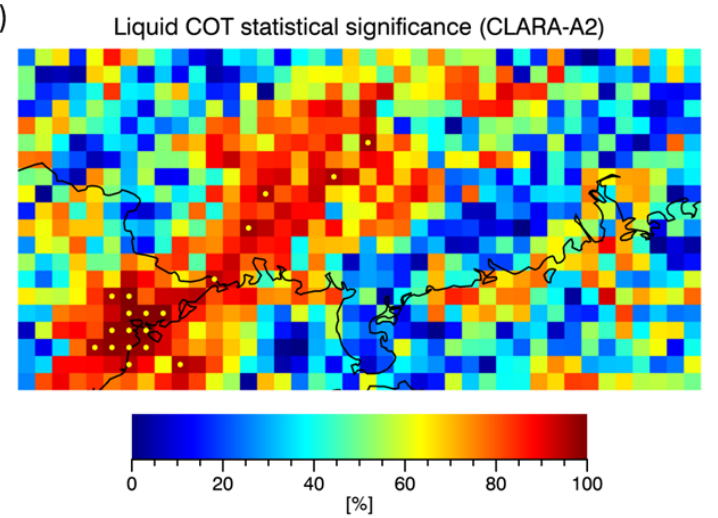

(d)

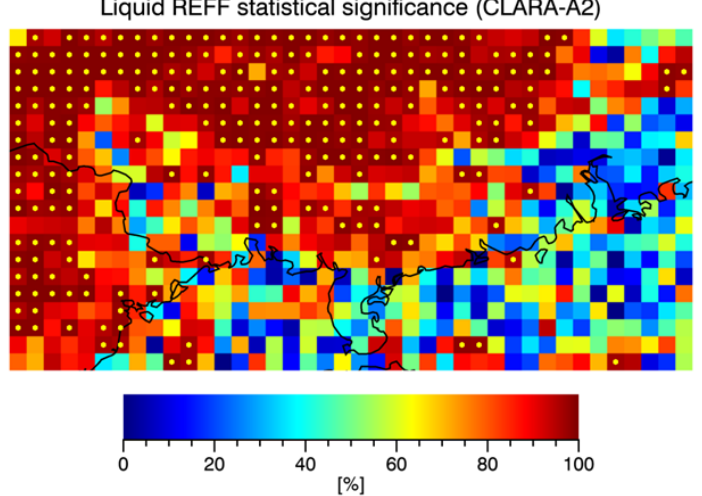

Figure 59. Spatial distributions $(a, c)$ and levels of statistical significance (b, $d$ ) for CLARA-A2 liquid COT and REFF changes over southern China, calculated for the period 2006-2015. The yellow dots in (b) and (d) highlight the grid cells where the level of statistical significance is higher than $95 \%$. 
(a)

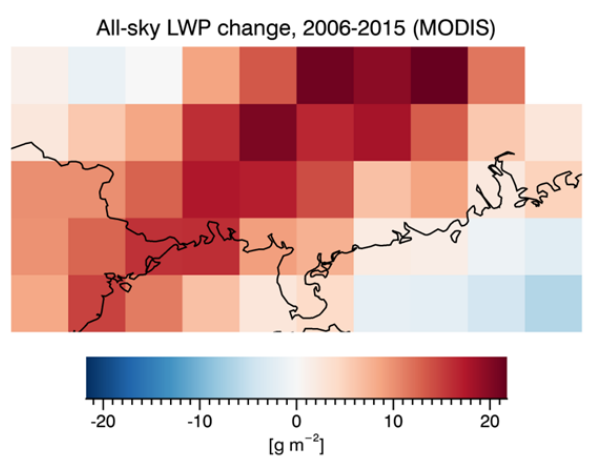

(c)



(e)

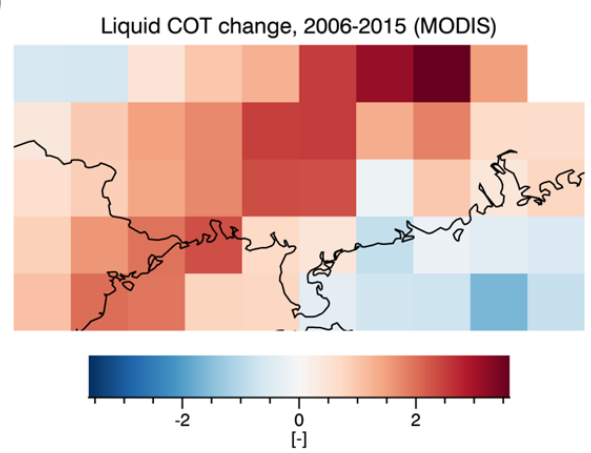

(g)

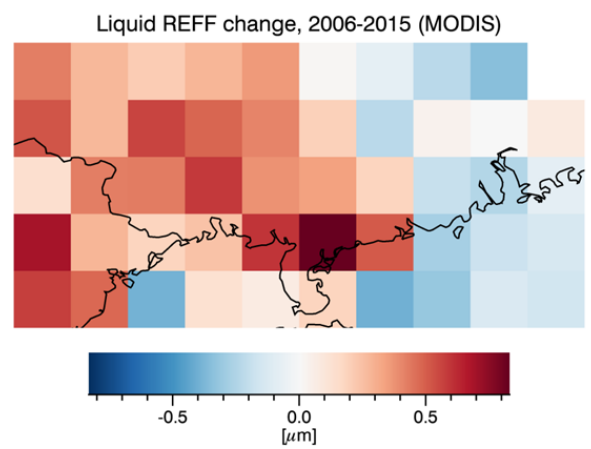

(b)

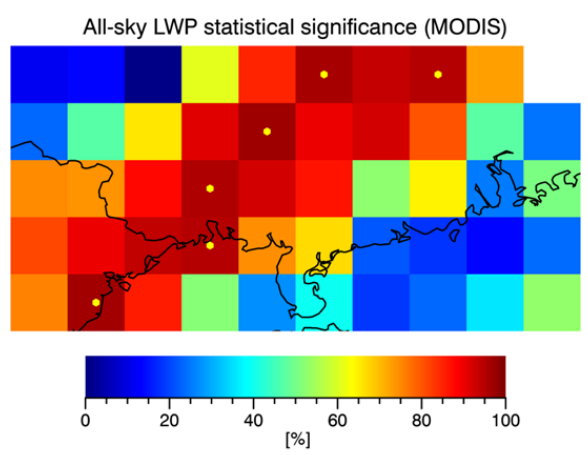

(d)



(f)

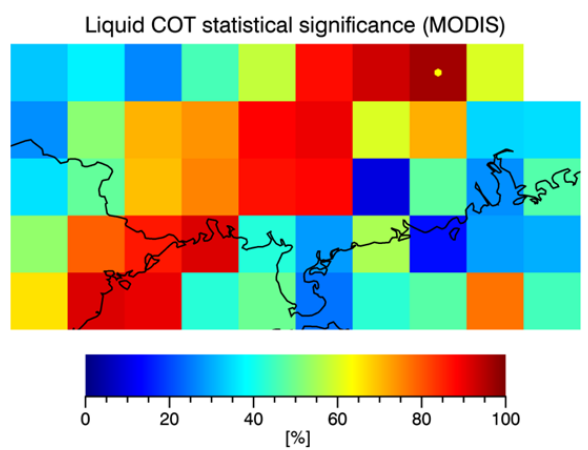

(h)

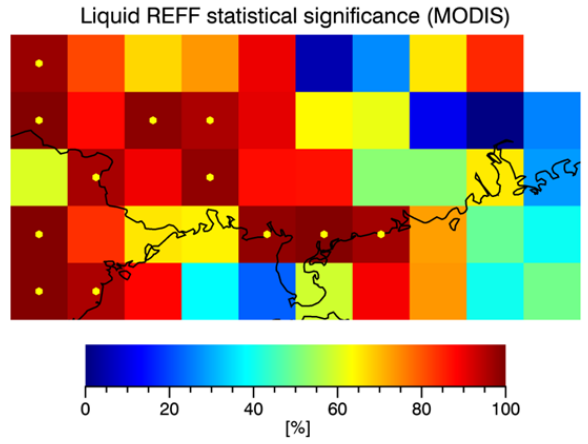

Figure S10. Spatial distributions $(a, c, e, g)$ and levels of statistical significance $(b, d, f, h)$ for MODIS all-sky LWP, liquid CFC, COT and REFF changes over southern China, calculated for the period 2006-2015. The yellow dots in (b), (d), (f) and (h) highlight the grid cells where the level of statistical significance is higher than $95 \%$. 
(a)



(b)

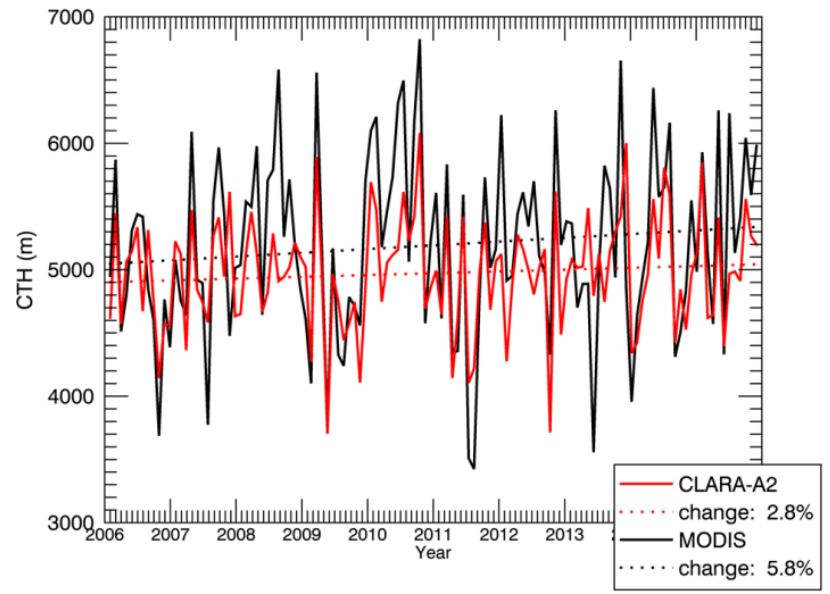

(c)

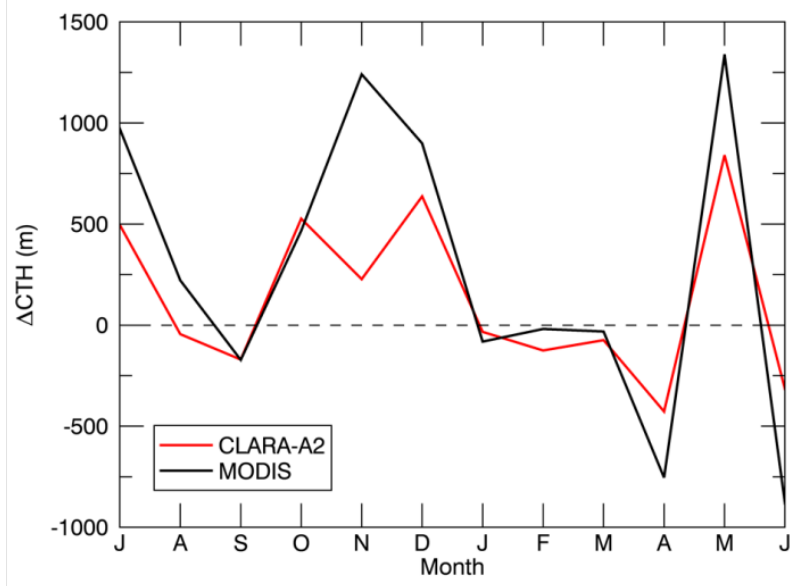

Figure S11. (a) Seasonal variation of Cloud Top Height (CTH) in the southern China study region based on CLARA-A2 and MODIS data. (b) Corresponding spatially averaged monthly deseasonalized values. The dotted lines correspond to the linear regression fits. (c) Seasonal variation of changes in CTH. Seasonal averages and changes in (a) and (c) are based on data from the period 2006-2015. 
Table S2. Levels of statistical significance of changes in cloud properties on a monthly basis, calculated from the period 20062015 separately for CLARA-A2 and MODIS.

\begin{tabular}{|l|r|r|r|r|r|r|r|r|r|r|}
\hline & \multicolumn{2}{|c|}{ All-sky LWP } & \multicolumn{2}{c|}{ Liquid CFC } & \multicolumn{2}{c|}{ In-cloud LWP } & \multicolumn{2}{c|}{ Liquid COT } & \multicolumn{2}{c|}{ Liquid REFF } \\
\hline & CLARA & \multicolumn{1}{|c|}{ MODIS } & \multicolumn{1}{|c|}{ CLARA } & \multicolumn{1}{c|}{ MODIS } & CLARA & MODIS & CLARA & MODIS & CLARA & MODIS \\
\hline Jan & 14.13 & 13.49 & 54.18 & 39.26 & 6.15 & 5.13 & 3.59 & 6.41 & 14.13 & 56.52 \\
\hline Feb & 10.79 & 3.68 & 44.67 & 39.57 & 10.60 & 15.01 & 5.28 & 1.13 & 14.10 & 52.25 \\
\hline Mar & 5.52 & 15.19 & 1.47 & 12.82 & 12.85 & 7.65 & 12.19 & 11.08 & 47.77 & 45.10 \\
\hline Apr & 33.05 & 42.88 & 28.30 & 4.58 & 58.39 & 61.04 & 50.12 & 54.49 & 73.79 & 72.08 \\
\hline May & 79.19 & 94.20 & 61.31 & 30.53 & 96.01 & 99.22 & 85.28 & 95.12 & 86.93 & 48.38 \\
\hline Jun & 13.69 & 26.27 & 85.18 & 49.95 & 39.64 & 62.92 & 36.34 & 55.18 & 61.09 & 59.25 \\
\hline Jul & 22.71 & 39.33 & 2.57 & 56.52 & 26.96 & 26.94 & 23.06 & 2.27 & 90.11 & 93.16 \\
\hline Aug & 4.06 & 77.65 & 57.83 & 42.97 & 74.50 & 29.39 & 34.42 & 1.00 & 86.12 & 97.35 \\
\hline Sep & 36.62 & 27.02 & 55.97 & 37.12 & 30.88 & 33.54 & 21.79 & 22.90 & 92.01 & 46.53 \\
\hline Oct & 46.82 & 69.47 & 74.85 & 81.51 & 72.35 & 70.81 & 59.18 & 66.37 & 79.20 & 50.22 \\
\hline Nov & 90.07 & 90.99 & 99.26 & 99.55 & 65.37 & 86.26 & 48.39 & 78.23 & 89.59 & 88.76 \\
\hline Dec & 97.05 & 99.33 & 35.75 & 54.15 & 99.43 & 99.91 & 96.45 & 98.57 & 97.46 & 67.40 \\
\hline
\end{tabular}


Table S3. Linear correlation coefficients of two-month-mean GFED BC and OC emission and AOD time series with cloud property time series over southern China during the period 2006-2015 (2007-2015 for CALIPSO AOD). Significant correlations are indicated with boldface.

\begin{tabular}{|c|c|c|}
\hline \multirow[t]{2}{*}{ parameter } & \multicolumn{2}{|c|}{ Jan-Feb/Mar-Apr/May-Jun/Jul-Aug/Sep-Oct/Nov-Dec } \\
\hline & CLARA liquid CFC & MODIS liquid CFC \\
\hline GFED emissions & $-0.62 /-0.75 / 0.19 / 0.39 /-0.03 /-0.54$ & $-0.67 /-0.66 /-0.09 / 0.26 / 0.09 /-0.54$ \\
\hline CALIPSO total AOD & $-0.22 /-0.59 / 0.34 / 0.77 /-0.06 /-0.77$ & $-0.22 /-0.50 / 0.44 / 0.39 /-0.16 /-0.75$ \\
\hline MODIS total AOD & $-0.45 / 0.33 / 0.57 / 0.15 / 0.27 /-0.76$ & $-0.44 / 0.16 / 0.46 / 0.36 / 0.38 /-0.81$ \\
\hline MISR total AOD & $-0.51 / 0.30 / 0.29 /-0.20 / 0.23 /-0.66$ & $-0.46 / 0.15 / 0.29 / 0.05 / 0.23 /-0.74$ \\
\hline MISR fine mode AOD & $-0.39 / 0.31 / 0.45 /-0.12 / 0.26 /-0.66$ & $-0.38 / 0.15 / 0.44 / 0.21 / 0.25 /-0.74$ \\
\hline \multirow[t]{2}{*}{ MISR coarse mode AOD } & $-0.57 / 0.30 / 0.13 /-0.28 / 0.14 /-0.62$ & $-0.50 / 0.19 / 0.14 /-0.25 / 0.14 /-0.69$ \\
\hline & CLARA all-sky LWP & MODIS all-sky LWP \\
\hline GFED emissions & $-0.50 /-0.33 / 0.09 / 0.52 / 0.04 /-0.72$ & $-0.49 /-0.17 /-0.02 / 0.09 /-0.02 /-0.77$ \\
\hline CALIPSO total AOD & $-0.16 /-0.31 / 0.55 / 0.41 /-0.31 /-0.69$ & $-0.15 /-0.19 / 0.57 /-0.56 /-0.35 /-0.71$ \\
\hline MODIS total AOD & $-0.45 /-0.13 / 0.52 /-0.06 /-0.21 /-0.75$ & $-0.41 /-0.34 / 0.29 /-0.02 /-0.37 /-0.84$ \\
\hline MISR total AOD & $-0.36 /-0.25 / 0.38 /-0.31 /-0.24 /-0.66$ & $-0.27 /-0.49 / 0.28 / 0.08 /-0.48 /-0.81$ \\
\hline MISR fine mode AOD & $-0.17 /-0.16 / 0.52 /-0.22 /-0.27 /-0.70$ & $-0.11 /-0.36 / 0.37 / 0.15 /-0.50 /-0.84$ \\
\hline \multirow[t]{2}{*}{ MISR coarse mode AOD } & $-0.55 /-0.29 / 0.22 /-0.43 /-0.27 /-0.55$ & $-0.47 /-0.55 / 0.16 /-0.12 /-0.49 /-0.72$ \\
\hline & CLARA CTH & MODIS CTH \\
\hline GFED emissions & $0.07 / 0.22 /-0.27 /-0.16 /-0.30 /-0.03$ & $-0.21 / 0.27 /-0.04 /-0.30 /-0.44 /-0.66$ \\
\hline CALIPSO total AOD & $0.44 / 0.62 / 0.21 /-0.40 /-0.01 / 0.34$ & $0.20 / 0.25 / 0.13 /-0.63 / 0.10 /-0.34$ \\
\hline MODIS total AOD & $0.08 /-0.04 /-0.32 /-0.34 /-0.53 /-0.14$ & $-0.44 / 0.11 / 0.09 /-0.39 /-0.49 /-0.74$ \\
\hline MISR total AOD & $0.30 /-0.29 / 0.04 /-0.13 /-0.43 /-0.27$ & $-0.14 /-0.50 / 0.59 /-0.06 /-0.36 /-0.73$ \\
\hline MISR fine mode AOD & $0.19 /-0.19 /-0.10 /-0.25 /-0.46 /-0.30$ & $-0.12 /-0.33 / 0.41 /-0.13 /-0.39 /-0.78$ \\
\hline \multirow[t]{2}{*}{ MISR coarse mode AOD } & $0.45 /-0.35 / 0.19 / 0.16 /-0.35 /-0.21$ & $-0.07 /-0.61 / 0.73 / 0.11 /-0.26 /-0.60$ \\
\hline & GPCP Precipitation & \\
\hline GFED emissions & $-0.12 /-0.19 / 0.48 /-0.53 /-0.27 /-0.62$ & \\
\hline CALIPSO total AOD & $-0.03 / 0.35 / 0.50 /-0.59 /-0.44 /-0.25$ & \\
\hline MODIS total AOD & $-0.22 / 0.44 / 0.56 /-0.12 /-0.82 /-0.63$ & \\
\hline MISR total AOD & $0.10 / 0.50 / 0.61 / 0.20 /-0.66 /-0.70$ & \\
\hline MISR fine mode AOD & $0.19 / 0.41 / 0.63 / 0.09 /-0.68 /-0.71$ & \\
\hline MISR coarse mode AOD & $-0.02 / 0.57 / 0.49 / 0.34 /-0.55 /-0.65$ & \\
\hline
\end{tabular}


(a)

500 hPa geopotential height, 2006-2015 (CAMS)
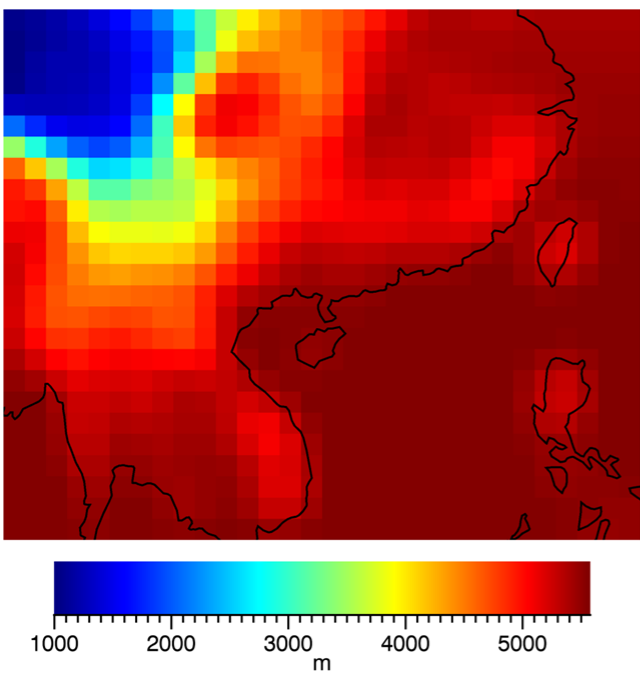

(c)
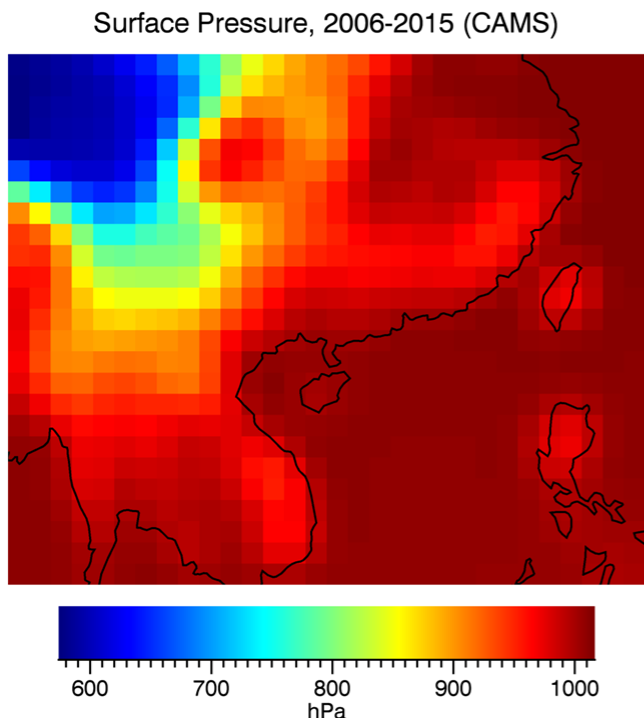

(b) $500 \mathrm{hPa}$ geopotential height change, 2006-2015 (CAMS)
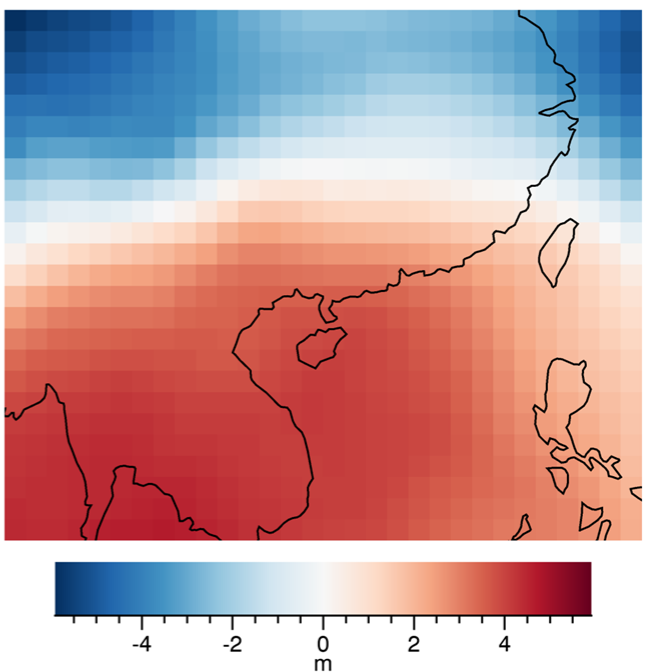

(d)

Surface Pressure change, 2006-2015 (CAMS)
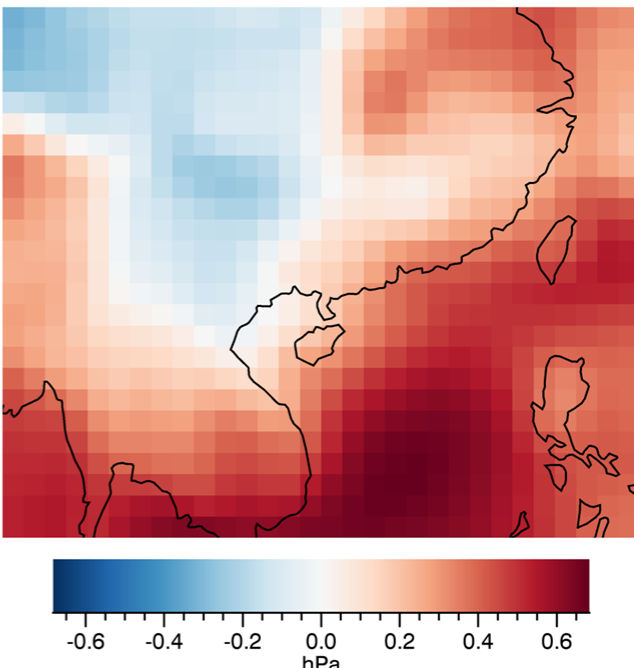

Figure S12. Average spatial distributions and corresponding changes in $\mathbf{5 0 0} \mathrm{hPa}$ geopotential height (a and b, respectively) and surface pressure ( $c$ and $d$, respectively) from the Copernicus Atmospheric Monitoring Service (CAMS) reanalysis over a wide area of southeast Asia, centered around the southern China study region. Averages were computed from monthly values during the period 2006-2015. Pixel-level changes were computed based on linear regressions fits to the deseasonalized monthly time series. 